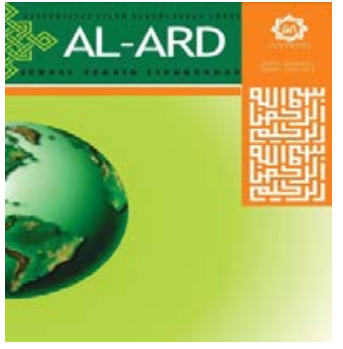

AL-ARD: JURNAL TEKNIK LINGKUNGAN

Vol. 3 No.1 - September 2017 (01-05)

AL-ARD

JURNAL

TEKNIK LINGKUNGAN

www.al-ard.uinsby.ac.id

\title{
DISTRIBUSI LOGAM BERAT TIMBAL DI PERAIRAN LAUT KAWASAN PESISIR GRESIK
}

\author{
Ayu Nindyapuspa', Achmad Chusnun Ni'am ${ }^{1}$ \\ ${ }^{1}$ Institut Teknologi Adhi Tama Surabaya, Indonesia \\ ayunindyapuspa@itats.ac.id \\ ach.niam@gmail.com
}

\begin{abstract}
The increasing of industrial activity on the Gresik Regency will increase the generated waste. One of the generated waste from industrial activity is hazardous waste which contain Lead $(\mathrm{Pb}) . \mathrm{Pb}$ which are disposed to the environment, especially to the sea, will pollute the environment and endanger the life of marine animals like fishes and other marine biota. Therefore, the research of $\mathrm{Pb}$ distribution was conducted on the coastal area of Gresik Regency. Sea water samples were taken from 3 different points, Petrokimia Port, Manyar Sub-regency, and Maspion V Industrial Area. Sampling used purposive sample method and samples were analyzed by AAS. Results showed that the highest $\mathrm{Pb}$ concentration at Maspion V Industrial area $(0.083$ $\mathrm{mg} / \mathrm{L})$. Meanwhile the lowest $\mathrm{Pb}$ concentration at Manyar Sub-regency $(0.021 \mathrm{mg} / \mathrm{L})$. Industrial activity that are conducted at Gresik Regency may generate $\mathrm{Pb}$ which can pollute the seawater.

Keywords: coastal area, Gresik, hazardous waste, lead, seawater,
\end{abstract}

\begin{abstract}
Abstrak
Meningkatnya kegiatan industri di Kabupaten Gresik dapat meningkatkan jumlah limbah yang dihasilkan. Salah satu limbah yang dihasilkan dari kegiatan industri adalah limbah B3 yang banyak mengandung timbal. Timbal yang dibuang ke lingkungan, terutama ke laut dapat mencemari lingkungan dan membahayakan kehidupan binatang laut seperti ikan dan biota laut lainnya. Oleh karena itu, diperlukan penelitian mengenai distribusi pencemaran timbal di perairan laut di kawasan pesisir Gresik. Sampel air laut diambil di tiga titik yang berbeda, yaitu kawasan pelabuhan PT Petrokimia Gresik, Kecamatan Manyar, dan Kawasan Industri Maspion V. Pengambilan sampel menggunakan metode purposive sample dan diujikan menggunakan AAS. Hasil menunjukkan bahwa pencemaran timbal terbesar berada di perairan laut di Kawasan Industri V Maspion (0,083 mg/L). Sedangkan pencemaran timbal terendah berada di kawasan Kecamatan Manyar (0,021 mg/L). Kegiatan industri yang dilakukan di Kabupaten Gresik dapat menghasilkan limbah timbal yang dapat mencemari air laut.

Kata Kunci: air laut, Gresik, limbah B3, pesisir, timbal
\end{abstract}

\section{PENDAHULUAN}

Kabupaten Gresik merupakan Kabupaten dengan kegiatan industri yang tinggi. Berdasarkan data Badan Pusat Statistik Kabupaten Gresik tahun 2013, industri besar dan sedang di Kabupaten Gresik mencapai 402 buah. Sebagian besar industri tersebut terletak di lokasi Cerme, Driyorejo, dan Kebomas. Terdapat tiga kecamatan di Kabupaten Gresik yang memiliki peningkatan pertumbuhan dan aktivitas jumlah industri, yaitu Kecamatan Gresik, Kecamatan Kebomas, dan Kecamatan Manyar. Beberapa industri di Gresik merupakan industri besar, salah satunya adalah PT. Petrokimia Gresik dan Kawasan Industri Maspion V. PT Petrokimia Gresik dikenal dengan produksi pupuk. Selain pupuk, PT. Petrokimia Gresik juga memroduksi

Industri memiliki dampak positif yaitu dapat menyerap tenaga kerja serta meningkatkan Anggaran Pendapatan Belanja Daerah (APBD). Akan tetapi, sama dengan kegiatan manusia lainnya, suatu kegiatan 
industri selalu menghasilkan limbah dan dapat mencemari lingkungan, jika tidak dapat tertangani dengan baik. Aktivitas pelabuhan juga dapat menjadi salah satu sumber pencemaran logam berat di perairan sekitarnya. Salah satu jenis pencemar yang dihasilkan oleh industri adalah limbah Bahan Berbahaya dan Beracun (Limbah B3). Berdasarkan PP Nomor 101 Tahun 2014, limbah B3 merupakan sisa kegiatan karena sifat, konsentrasi, atau jumlahnya dapat merusak lingkungan hidup dan dapat membahayakan kelangsungan hidup manusia dan makhluk hidup lain. Limbah B3 selalu menjadi permasalahan yang serius hampir di setiap industri. Sebanyak $66,4 \%$ dihasilkan oleh industri di Gresik, yaitu 12,9 juta ton per tahun atau 1,1 juta ton per bulan. Wilayah pesisir lebih rentan terhadap pembuangan limbah dari kegiatan industri. Terlebih lagi, PT Petrokimia Gresik dan Kawasan Industri Maspion V terletak di dekat laut di Kawasan Pesisir Gresik. Toksisitas logam berat tersebar luas mengontaminasi lingkungan di perairan pesisir Indonesia. Kontaminasi logam berat yang tinggi telah sebagian besar disimpan di pantai utara Pulau Jawa dan pantai timur Pulau Sumatra. Apabila tidak tertangani dengan baik, maka limbah B3 dapat membahayakan kelangsungan hidup makhluk lain di perairan laut dan akan membahayakan manusia secara tidak langsung. Limbah B3 yang mengandung logam berat berbahaya bagi lingkungan karena bersifat toksik. Salah satu jenis logam berat yang sering dijumpai adalah timbal $(\mathrm{Pb})$. Timbal merupakan salah satu logam berat yang dapat dihasilkan dari emisi kendaraan bermotor dan kegiatan industri. Dalam indusri, timbal digunakan dalam bidang otomotif, pembuatan keramik, industri plastik PVC dan solder. Logam berat $\mathrm{Pb}$ juga biasa digunakan dalam campuran cat, pestisida serta campuran dalam bahan bakar kendaraan. Kemampuan timbal dalam membentuk alloy dengan logam lain dimanfaatkan untuk sebagian besar industri, contohnya untuk kabel listrik, konstruksi pabrik-pabrik kimia, dan kontainer, karena tahan terhadap korosi. Hampir 10\% dari total produksi penambangan timbal digunakan dalam proses produksi bahan bakar bensin karena dapat mendongkrak (boosting) nilai oktan bahan bakar sekaligus berfungsi sebagai antiknocking untuk mencegah terjadinya ledakan saat berlangsungnya pembakaran dalam mesin.

Timbal merupakan mineral yang tergolong mikroelemen dan berpotensi menjadi bahan toksik. Masuknya Pb ke dalam tubuh makhluk hidup dapat melalui saluran pencernaan (gastrointestinal), saluran pernafasan (inhalasi), dan penetrasi melalui kulit (topikal). Keberadaan bahan pencemar seperti logam berat di wilayah pesisir akan berbahaya bagi kesehatan manusia dan biota di perairan. Bila logam berat timbal masuk ke dalam tubuh manusia, maka logam berat tersebut tidak bisa diekskresikan lagi ke luar tubuh. Dampak negatif yang dapat ditimbulkan akibat timbal adalah: 1) menghambat aktivitas enzim sehingga proses metabolisme terganggu, 2) menyebabkan abnormalitas kromosom, 3) menghambat perkembangan janin, 4) menurunkan fertilitas wanita, 5) menghambat pembentukan sel sperma pada pria, 6) mengurangi konduksi syaraf tepi, 7) menghambat pembentukan hemoglobin, 8) menyebabkan kerusakan ginjal, 9) menyebabkan kekurangan darah, 10) pembengkakkan kepala, dan 11) menyebabkan gangguan emosional dan tingkah laku.

Pencemaran laut diartikan sebagai adanya kotoran atau hasil buangan aktivitas makhluk hidup yang masuk ke daerah laut. Sumber dari pencemaran laut dapat berupa sisa damparan amunisi perang, buangan dan proses di kapal, buangan industri ke laut, proses pengeboran minyak di laut, buangan sampah dari transportasi laut, dan buangan pestisida dari pertanian. Peningkatan kadar logam berat pada air laut dapat berubah menjadi racun bagi organisme laut. Selain bersifat racun, logam berat di perairan juga akan terakumulasi dalam sedimen yang pada gilirannya juga dapat terakumulasi oleh organisme. Logam berat $\mathrm{Pb}$ dapat menyebabkan keracunan akut dan kronis yang ditandai diare, mual-mual, dan anemia. Salah satu cara melindungi kualitas perairan dan kesehatan manusia di daerah pesisir Gresik, maka perlu dilakukan pengukuran kadar bahan bahan pencemar di perairan dan sedimen, sehingga diketahui profil konsentrasi bahan pencemar. Data yang diperoleh nantinya dapat digunakan sebagai baseline data dan monitoring lingkungan lanjutan, serta menilai konsentrasi bahan pencemar untuk masa yang akan datang. 


\section{METODE PENELITIAN}

Sampel yang diambil berupa air laut yang diambil di kawasan perairan yang padat dengan aktivitas industri. Jumlah titik sampel yang diambil adalah 3 titik, yaitu di daerah Kecamatan Manyar, Pelabuhan PT Petrokimia Gresik, dan sekitar Kawasan Industri Maspion V. Pengambilan sampel dilakukan pada pagi hari pukul 07.00 - 10.00 WIB. Pukul 07.00 hingga 10.00 WIB dipilih karena pada jam-jam tersebut digunakan manusia untuk beraktivitas, baik aktivitas di rumah maupun aktivitas di lingkungan industri. Pengambilan sampel dilakukan dengan metode purposive sampling. Air laut diambil menggunakan nansen water sampler.

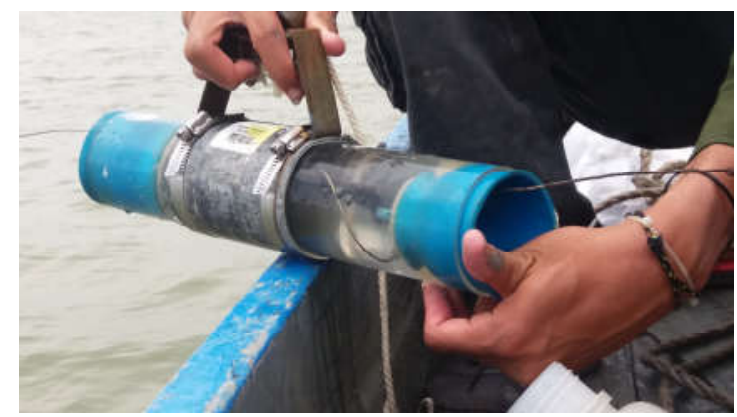

Gambar 1. Nansen water sampler

Kemudian, sampel air laut tersebut dimasukkan ke dalam botol High Density Poly Ethylene (HDPE), kemudian diawetkan dengan asam nitrat $\left(\mathrm{HNO}_{3}\right)$ hingga $\mathrm{pH}$ mencapai 2 dan disimpan dalam ice box. Data klimatologi (curah hujan, arah, dan kecepatan angin) pada waktu pengambilan sample didapat dari Stasiun Metereologi Perak I Surabaya. Jumlah industri diperoleh dari hasil sekunder melalui Dinas Perindustrian Kabupaten Gresik.

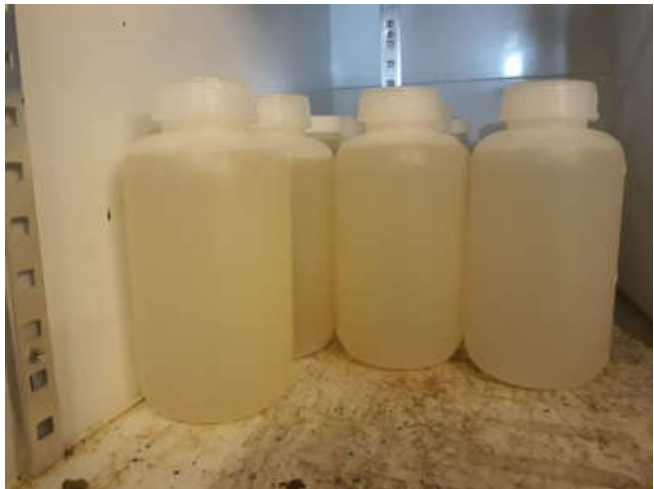

Gambar 2. Sampel Air Laut dalam Botol HDPE

Setelah itu, sampel air laut dianalisis kadar timbalnya dengan menggunakan Atomic Absorption Spectrophotometry (AAS). Data yang diperoleh akan dibandingkan dengan penelitian serupa yang telah dilakukan dan Keputusan Menteri Negara Lingkungan Hidup Nomor 51 Tahun 2004 Tentang
Baku Mutu Air Laut. Data yang diperoleh disajikan dalam bentuk tabel dan dibahas secara deskriptif.

\section{HASIL DAN PEMBAHASAN}

Penelitian dilakukan di kawasan pesisir Kabupaten Gresik dengan mengambil 3 stasiun sampling yang berada di sepanjang kawasan pesisir di daerah Kecamatan Gresik dan Kecamantan Manyar. Pengambilan sampel air laut dilakukan pada tanggal 28 Januari 2017. Pengambilan sampel air dan sedimen dilakukan di kawasan pesisir daerah Kecamatan Gresik dan Kecamatan Manyar dikarenakan di sepanjang kawasan pesisir kedua kecamatan ini berdiri beberapa industri seperti, PT. Petrokimia Gresik dan Kawasan Industri Maspion V. Pemilihan titik pengambilan sampel yang berbeda ini bertujuan untuk membandingkan konsentrasi $\mathrm{Pb}$ antara kawasan multi industri, industri petrokimia, dan kawasan permukiman penduduk. Besar kecilnya suatu pencemaran timbal dipengaruhi oleh kegiatan manusia. Lokasi pengambilan sampel air laut dapat dilihat pada Gambar 3.

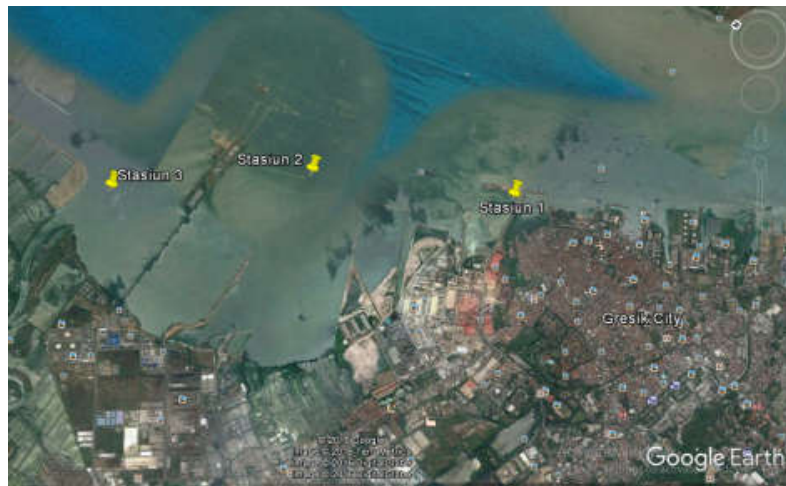

Gambar 3. Lokasi Pengambilan Sampel Air Laut

Stasiun 1 terletak di kawasan Pelabuhan PT Petrokimia Gresik. Di kawasan perairan laut di stasiun 1, terdapat banyak kapal-kapal yang berkumpul di Pelabuhan PT. Petrokimia Gresik. Stasiun 2 terletak di kawasan Industri Maspion V. Stasiun 3 terletak di sekitar muara sungai di Kecamatan Manyar yang dekat dengan permukiman penduduk.

Suhu saat pengambilan sampel adalah sekitar $27,3^{\circ} \mathrm{C}$, kelembaban rata-rata $87 \%$, dan curah hujan 12,5 mm. Berdasarkan Stasiun Meteorologi Perak I Surabaya, kecepatan angin saat itu berkisar antara 5-8 knot ke arah barat laut. Ketika pengambilan sample di 3 stasiun, kondisi cuaca berubah-ubah dan sempat terjadi hujan ringan selama \pm 30 menit. Koordinat lokasi pengambilan sampel air laut dan sedimen untuk masing-masing stasiun dapat dilihat pada Tabel 1 .

Tabel 1. Koordinat Lokasi Pengambilan Sampel Air Laut 


\begin{tabular}{cl}
\hline Lokasi & \multicolumn{1}{c}{ Koordinat } \\
\hline Stasiun 1 & $7^{\circ} 8$ '36.40"S dan $112^{\circ} 39^{\prime} 25.80 " \mathrm{E}$ \\
\hline Stasiun 2 & $7^{\circ} 7^{\prime} 17.50^{\prime \prime} \mathrm{S}$ dan $112^{\circ} 38^{\prime} 50.10 " \mathrm{E}$ \\
\hline Stasiun 3 & $7^{\circ} 6^{\prime} 8.40 " \mathrm{~S}$ dan $112^{\circ} 37^{\prime} 58.80 " \mathrm{E}$ \\
\hline Sumber: Hasil Pengukuran
\end{tabular}

Dari ketiga lokasi tersebut, diambil sampelnya dan diawetkan dengan asam nitrat hingga $\mathrm{pH}$ nya menjadi 2. Tujuan penambahan asam nitrat ke dalam sampel air laut adalah untuk mengawetkan sampel dan untuk mengekstraksi logam berat yang terkandung di dalam air laut. Selain itu botol HDPE juga dipilih karena botol HDPE dianggap tidak dapat bereaksi dengan sampel air laut yang telah ditambahkan asam nitrat. Setelah itu sampel disimpan ke dalam ice box.

Setelah sampel air laut diawetkan, sampel tersebut dibawa ke AAS untuk diketahui konsentrasi timbalnya. Hasil pengujian timbal dapat dilihat pada Tabel 2 .

Tabel 2. Hasil Pengujian Kadar Timbal Air Laut di Kawasan Pesisir Gresik

\begin{tabular}{cc}
\hline Lokasi & Kadar Timbal (mg/L) \\
\hline Stasiun 1 & 0,056 \\
\hline Stasiun 2 & 0,083 \\
\hline Stasiun 3 & 0,021 \\
\hline Baku mutu* & 0,005 \\
\hline $\begin{array}{l}\text { Sumber: Hasil Pengukuran } \\
\text { *Berdasarkan KepmenLH 51 Tahun2004 }\end{array}$
\end{tabular}

Berdasarkan hasil perbandingan hasil uji dengan baku mutu yang sesuai dan masih berlaku, konsentrasi timbal di Stasiun 1, 2, dan 3 melampaui baku mutu berdasarkan KepmenLH 51 Tahun 2004 tentang Baku Mutu Air Laut. Konsentrasi $\mathrm{Pb}$ tertinggi terletak pada Stasiun 2, yaitu terletak di Kawasan Industri Maspion V. Sedangkan, konsentrasi $\mathrm{Pb}$ terendah terletak pada Stasiun 3, yaitu di Kawasan Kecamatan Manyar yang dekat dengan permukiman penduduk. Di dalam kawasan perairan, laut juga memiliki sedimen. Logam berat yang terkandung di dalam air laut dapat mengendap dan membentuk sedimen. Akan tetapi, dalam penelitian ini menunjukkan bahwa kandungan timbal dalam sedimen lebih kecil dibandingkan kandungan timbal di air laut. Kadar timbal dalam sedimen adalah $<0,023 \mathrm{mg} / \mathrm{kg}$. Hal ini disebabkan bahwa timbal tidak sempat mengendap dan kandungan timbal di permukaan laut masih tinggi. Pengambilan sampel air laut tidak dilakukan terlalu dalam, sehingga yang terambil adalah permukaan air lautnya saja. Menurut Siaka (2016), penggunaan air laut sebagai sampel memiliki kelemahan karena pergerakan dari air laut yang tidak tetap dan berubah-ubah. Kecepatan dan arah angin yang berubah-ubah ini dapat menyebabkan distribusi timbal di perairan laut di pesisir Gresik juga dapat berubah-ubah. Pada saat pengambilan

p-ISSN: 2460-8815, e-ISSN: 2549-1652 sampel, angin bergerak ke arah barat laut, sehingga konsentrasi timbal yang terdapat di stasiun 2 paling tinggi di antara stasiun yang lainnya. Grafik konsentrasi $\mathrm{Pb}$ di perairan laut pesisir Gresik dapat dilihat pada Gambar 4.

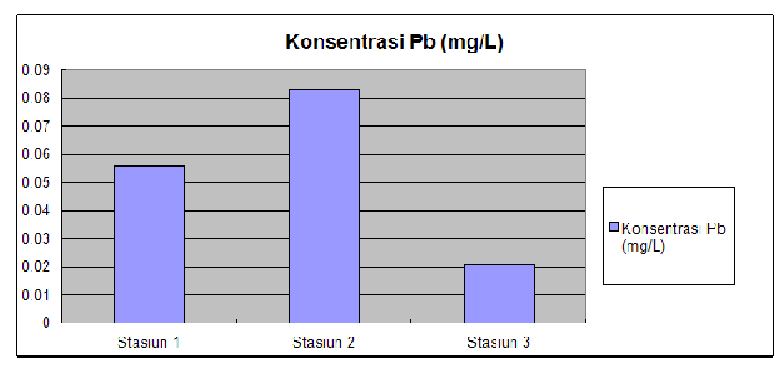

Gambar 4. Grafik Konsentrasi Pb di Perairan Laut Pesisir Gresik

Penelitian ini dibandingkan dengan penelitian serupa yang dilakukan di tempat lain. Berdasarkan penelitian Usman dkk (2013), logam Pb dengan konsentrasi tinggi ditemukan di perairan pelabuhan Parepare sebesar 0,038 mg/L. Sumber pencemar $\mathrm{Pb}$ dapat berupa tumpahan-tumpahan minyak yang terjadi di sekitar pelabuhan apabila ada aktifitas bongkar muat minyak ke darat. Selain kegiatan bongkar muat, pencemaran logam $\mathrm{Pb}$ juga disebabkan oleh adanya kapal yang melewati kawasan industri tersebut, sehingga kemungkinan ceceran minyak juga dapat terjadi (Usman dkk, 2013). Selain dari penelitian Usman dkk (2013), penelitian ini juga dibandingkan dengan penelitian serupa yang dilakukan di lokasi lain. Perbandingan kadar $\mathrm{Pb}$ di setiap lokasi penelitian dapat dilihat pada Tabel 3.

Tabel 3. Perbandingan Kadar Pb di Lokasi Penelitian Lain

\begin{tabular}{lll}
\hline Lokasi Penelitian & $\begin{array}{c}\text { Kadar Pb } \\
\text { (mg/L) }\end{array}$ & Referensi \\
\hline $\begin{array}{l}\text { Kemaman coast } \\
\text { Malaysia }\end{array}$ & $\begin{array}{l}0,006- \\
0,980\end{array}$ & Ahmad, 1996 \\
\hline Gulf of Suez & $0,56-3,17$ & Hatje dkk, 2001 \\
\hline Masan Bay, Korea & 0,64 & $\begin{array}{l}\text { Kwon dan Lee, } \\
2001\end{array}$ \\
\hline $\begin{array}{l}\text { Singapore coastal } \\
\text { waters }\end{array}$ & $0,006-$ & Cuong dkk, 2005 \\
\hline $\begin{array}{l}\text { Perairan Dumai, } \\
\text { Indonesia }\end{array}$ & $9,98-470$ & Amin dkk, 2009 \\
\hline $\begin{array}{l}\text { Perairan PT. } \\
\text { Marcopolo Batam, } \\
\text { Indonesia }\end{array}$ & $0,063-$ & Kennedy, 2011 \\
\hline $\begin{array}{l}\text { Perairan Industri } \\
\text { Galangan Kapal } \\
\text { Batam, Indonesia }\end{array}$ & $0,05-1,54$ & Kennedy, 2014 \\
\hline \multicolumn{1}{l}{ Sumber: Kennedy, 2014 } & \\
\hline
\end{tabular}

Sumber: Kennedy, 2014

Logam berat merupakan salah satu pencemar yang berbahaya, karena sifat toksisk jika dalam jumlah yang besar dan dapat mempengaruhi berbagai aspek dalam perairan baik aspek ekologis maupun aspek biologis. Logam-logam berat yang ada dalam 
badan air akan mengalami proses pengendapan dan terakumulasi dalam sedimen, kemudian terakumulasi dalam tubuh biota yang ada di dalamnya dan akhirnya akan sampai pada manusia jika organisme tersebut dikonsumsi (Wulan dkk, 2013).

Sumber pencemar logam berat dapat masuk ke perairan Kawasan Pesisir Gresik melalui aktivitas masyarakat seperti dari asap kendaraan, pertanian menggunakan pestisida, perbengkelan, kegiatan industri dan pembuangan sisa limbah rumah tangga (Amin, Afriyani, dan Saputra, 2011).

Logam berat yang terkandung dalam air laut juga dapat terakumulasi dalam hewan air. Selain konsentrasi logam dalam air laut, faktor akumulasi juga dipengaruhi oleh $\mathrm{pH}$ air laut dan sedimen, kadar COD dalam air laut, kandungan sulfur dalam air dan sedimen, jenis hewan air, umur dan bobot tubuh hewan air. Semakin rendah $\mathrm{pH}$ air laut, maka logam berat semakin larut dalam air (bentuk ion) sehingga semakin mudah masuk ke dalam tubuh hewan air, baik melalui insang, bahan makanan, atau melalu difusi (Sitorus, 2004).

Laut menjadi lokasi pembuangan akhir dari berbagai limbah, termasuk limbah yang mengandung timbal. Polutan yang masuk dapat masuk ke dalam air laut dan sedimen dan dapat membawa dampak yang luas mulai dari tingkat organisme sampai tingkat komunitas, bahkan meluas hingga ke tingkat ekosistem. Respon yang terjadi pada suatu ekosistem akuatik meliputi tahap-tahap yaitu biokonsentrasi, bioakumulasi, dan biomagnifikasi (Puspitasari, 2007). Biokonsentrasi merupakan kondisi adanya peningkatan konsentrasi polutan di lingkungan. Apabila suatu organisme mengalami paparan bahan toksik secara terus menerus, maka akan mengalami bioakumulasi. Sedangkan biomagnifikasi mengacu pada kecenderungan polutan untuk terkonsentrasi dan berpindah dari satu tingkat trofik ke tingkat berikutnya. Bila biomagnifikasi terus berlanjut, maka efeknya akan berdampak pada manusia sebagai konsumen tertinggi dalam jaring-jaring makanan.

\section{KESIMPULAN}

Hasil penelitian menunjukkan bahwa pencemaran timbal terbesar berada di perairan laut di Kawasan Industri V Maspion $(0,083 \mathrm{mg} / \mathrm{L})$. Sedangkan pencemaran timbal terendah berada di kawasan Kecamatan Manyar $(0,021 \mathrm{mg} / \mathrm{L})$. Kegiatan industri yang dilakukan di Kabupaten Gresik dapat menghasilkan limbah timbal yang dapat mencemari air laut. Untuk penelitian berikutnya harus dilakukan pengujian logam berat yang terakumulasi dalam organisme laut, untuk mengetahui kadar toksisitas yang masuk ke dalam tubuh binatang laut. Pengukuran $\mathrm{pH}$ dan suhu saat di lapangan juga perlu dilakukan untuk mengukur pengaruh $\mathrm{pH}$ terhadap kelarutan logam berat.

\section{DAFTAR PUSTAKA}

Amin, Bintal. Afriyani, Evy. Saputra, Mikel Adi. 2011. Distribusi Spasial Logam $\mathrm{Pb}$ dan $\mathrm{Cu}$ pada Sedimen dan Air Laut Permukaan di Perairan Tanjung Buton Kabupaten Siak Provinsi Riau. Jurnal Teknobiologi. Vol II(1). Hal. 1-8

Kennedy, Leo. Amin, Bintal. Anita, Sofia. 2014. Evaluasi Tingkat Pencemaran Logam Berat di Perairan Sekitar Area Industri Galangan Kapal Batam Provinsi Riau. Pusat Penelitian Lingkungan Hidup Universitas Riau.

Puspitasari, Rachma. 2007. Laju Polutan dalam Ekosistem Laut. Oseana, Vol. XXXII (2), Hal. 21-28.

Siaka, I Made. Suastuti, Ni Gusti Ayu Made Dwi Adhi. Dan Mahendra, I Putu Bagus. 2016. Distribusi Logam Berat Pb dan $\mathrm{Cu}$ pada Air Laut, Sedimen, dan Rumput Laut di Perairan Pantai Pandawa. Jurnal Kimia, Vol. 10 (2). Hal. 190-196.

Sitorus, Hasan. 2004. Analisis Beberapa Karakteristik Lingkungan Perairan yang Mempengaruhi Akumulasi Logam Berat Timbal dalam Tubuh Kerang Darah di Perairan Pesisir Timur Sumatera Utara. Jurnal Ilmu-Ilmu Perairan dan Perikanan Indonesia. Vol. XI (1). Hal. 53-60

Wulan, Sri Purnama. Thamrin. Amin, Bintal. 2013. Konsentrasii, Distribusi, dan Korelasi Logam Berat Pb, Cr, dan $\mathrm{Zn}$ pada Air dan Sedimen di Perairan Sungai Siak Sekitar Dermaga PT. Indah Kiat Pulp and Paper Perawang-Propinsi Riau. Pusat Penelitian Lingkungan Hidup Universitas Riau

Usman, Surahmi. Nafie, Nursiah La. Ramang, Musa. 2013. Distribusi Kuantitatif Logam Berat Pb dalam Air, Sedimen, dan Ikan Merah (Lutjanus erythropterus) di sekitar Perairan Pelabuhan Parepare. Marina Chimica Acta, Vol. 14 (2), Hal. 49-55 